\title{
Cultivation of choice: new insights into farming practices at Neolithic lakeshore sites
}

Amy Styring*,1, Ursula Maier ${ }^{2}$, Elisabeth Stephan ${ }^{3}$,
Helmut Schlichtherle ${ }^{2} \&$ Amy Bogaard

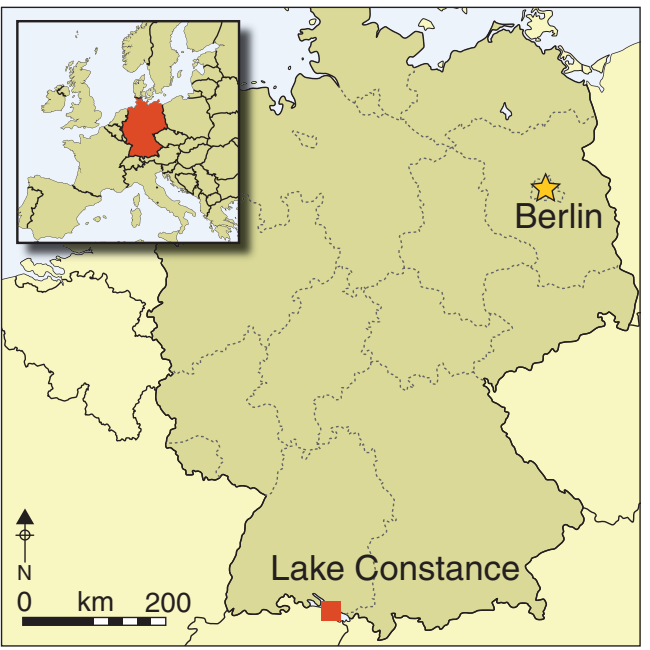

The high-quality organic preservation at Alpine lakeshore settlement sites allows us to go beyond simplistic reconstructions of farming in the Neolithic. The rich archaeological datasets from these sites may be further complemented by methods such as nitrogen isotope $\left(\delta^{15} N\right)$ analysis of charred crop remains. At Hornstaad-Hörnle IA and Sipplingen, on the shore of Lake Constance in south-west Germany, this method has been used to provide a unique insight into strategies of cultivation such as manuring on both a spatial and temporal scale.

Keywords: south-west Germany, Neolithic, Alpine foreland, agriculture, nitrogen isotopes, archaeobotany

\section{Introduction}

The lakeshore settlements (Pfablbausiedlungen) of the Alpine foreland offer a unique insight into the Neolithic way of life in this region. Excellent preservation of organic remains enables high-resolution dating of settlements through dendrochronology, and the wealth of organic artefacts and ecofacts permits a detailed understanding of subsistence practices. In this study, we explore the social and ecological implications of nitrogen isotopic determinations of charred crop remains, considering two contrasting situations on Lake Constance, south-west Germany: i) the 'isoscape' of an entire cereal harvest from a single year (3910 BC) at Hornstaad-Hörnle IA; and ii) long-term continuity and

1 School of Archaeology, 36 Beaumont Street, University of Oxford, Oxford OX1 2PG, UK (Email: amy.styring@arch.ox.ac.uk)

2 Landesamt für Denkmalpflege im Regierungspräsidium Stuttgart, Fischersteig 9, 78343 GaienhofenHemmenhofen, Germany

3 Landesamt für Denkmalpflege im Regierungspräsidium, Stromeyersdorfstrasse 3, 78467 Konstanz, Germany

* Author for correspondence

(C) Antiquity Publications Ltd, 2016. This is an Open Access article, distributed under the terms of the Creative Commons Attribution licence (http://creativecommons.org/licenses/by/4.0/), which permits unrestricted re-use, distribution, and reproduction in any medium, provided the original work is properly cited. 
change in crop-growing conditions over 1000 years at Sipplingen (c. 4000-2800 cal BC; Figure 1). The crop nitrogen isotope values are interpreted within the rich context of multi-stranded archaeological evidence recorded at these sites. Together, they enable new understandings of the social geography and ecology of early farming landscapes across a synchronous horizon at Hornstaad, and through a millennium of social and environmental change at Sipplingen.

\section{The nature of early farming on Lake Constance}

Although much is known about plant use at Neolithic lakeshore sites through the analysis of both carbonised and waterlogged macrobotanical remains (summarised in Jacomet \&

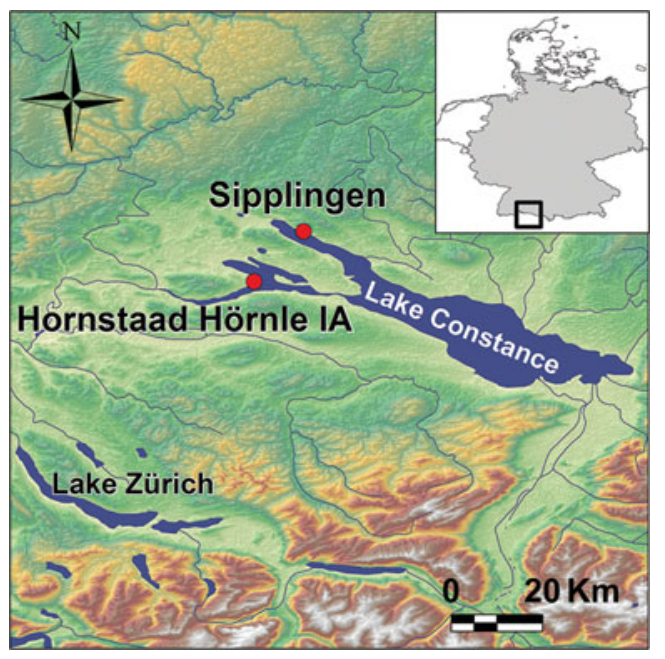

Figure 1. Map showing location of Hornstaad-Hörnle IA and Sipplingen in south-west Germany.

Brombacher 2005), less is known about the nature of farming itself-i.e. labour inputs, levels of manuring, longevity of cultivation and the interplay between crop and animal husbandry. Analysis of weed seeds often found associated with crop remains can reveal much about agricultural productivity, the degree of soil disturbance-relating to weeding and hoeing — and the permanence of plots (e.g. Bogaard 2004), but in order to relate weeds to a particular crop species, they must be found in pure crop samples. Few perennial or woodland species have been found in association with crop remains from lakeshore sites, indicating that cultivation was permanent on long-lived plots (e.g. Brombacher \& Jacomet 1997; Maier \& Vogt 2001: 84). Moreover, the weeds indicate a spectrum of relatively productive conditions (e.g. Bogaard 2004: 113), while variation in their prevalence and diversity between stores could indicate differences in weeding regimes between plots (e.g. Maier \& Vogt 2001: 94).

\section{Reconstructing past farming practices through crop nitrogen isotope values}

Crop nitrogen isotope $\left(\delta^{15} \mathrm{~N}\right)$ values integrate a range of environmental and physiological processes, but largely reflect the $\delta^{15} \mathrm{~N}$ value of the soil in which they are grown (e.g. Högberg 1997). Potential causes of high plant $\delta^{15} \mathrm{~N}$ are: recent forest clearance by burning, which volatilises ammonium (Ehrmann et al. 2014); loss of nitrogen through bacterially mediated denitrification, which occurs in seasonally waterlogged, anaerobic soils (Finlay \& Kendall 2008); and high levels of organic nitrogen relative to plant demand, leading to high microbial turnover and subsequent loss of nitrogen as ammonia and ammonium (Aguilera et al. 2008). All of these processes lead to preferential loss of ${ }^{14} \mathrm{~N}$, leaving ${ }^{15} \mathrm{~N}$-enriched nitrogen in the soil for plants to take up.

(C) Antiquity Publications Ltd, 2016 
A major influence on crop $\delta^{15} \mathrm{~N}$ values in agricultural systems is manuring. Studies of modern crops have found that manuring can increase cereal $\delta^{15} \mathrm{~N}$ values by as much as $10 \%$, according to the intensity—amount and frequency (e.g. Fraser et al. 2011). Based on these modern studies, cereal grain $\delta^{15} \mathrm{~N}$ values for high $(35+$ tonnes/ha), medium (1015 tonnes/ha) and low/no ( $<10$ tonnes/ha) levels of manuring have been estimated (see Figure 5; cf. Bogaard et al. 2013: fig. 1). Further, as changes in manuring levels take a number of years to register in crop $\delta^{15} \mathrm{~N}$ values (Fraser et al. 2011), any distinctions must reflect sustained differences in cultivation, indicating long-lived plots and land investment over many years.

Intensive manuring requires a high input of labour, and, in modern farming studies, is usually associated with small-scale, 'garden' cultivation (Halstead 1987). This usually goes hand-in-hand with other labour-intensive cultivation practices such as weeding and hoeing, thereby creating conditions that favour weed species able to thrive in disturbed soils. Crop nitrogen isotope analysis can, therefore, demonstrate whether the productive conditions indicated by weed seeds are also associated with manuring. As a finite resource, manure must be applied strategically to maximise yields and enable surpluses to buffer against potential future crop failures (Halstead 1989). Crop nitrogen isotope values can reflect these decisions for individual archaeological contexts, distinguishing household preferences, as well as identifying the more general intensity with which farming was practised, and whether this changed with fluctuations in climate, environment and cultural developments.

\section{Hornstaad-Hörnle IA}

Hornstaad-Hörnle IA is a Neolithic (3918-3902 cal BC) pile settlement (with houses raised on stilts) located on the shore of Lake Constance in south-west Germany (Figure 1). The first houses were built in $3918 \mathrm{cal} \mathrm{BC}$, and the village grew haphazardly, with no visible structural organisation or hierarchy (Billamboz 2006; Figure 2). In $3910 \mathrm{cal} \mathrm{BC \text {,a }}$ fire destroyed almost the entire village, preserving the remains of the houses and the crop harvest from this year in a single layer. The lake eroded away much of this burnt cultural deposit, but an area of c. $2500 \mathrm{~m}^{2}$, encompassing 21 houses, remained available for further investigation (centre of Figure 2). Systematic sampling over $211 \mathrm{~m}^{2}$ of this burnt layer at $1 \mathrm{~m}$ intervals (Figure 3 ) has revealed numerous crop stores containing thousands of exceptionally well-preserved carbonised cereal ears and loose grains. The high number of cereals and low number of wild plants place the fire in late summer/early autumn, shortly after the harvest but before wild foods such as hazelnuts and wild apples were ripe (Maier 1999). This burnt layer thus provides a high-resolution snapshot of village life shortly after the harvest, and an insight into crop cultivation practices carried out by different households (Maier 1999).

The harvest was dominated by tetraploid naked wheat (Triticum durum/turgidum type), followed by barley (Hordeum vulgare ssp. nudum), einkorn (T. monococcum) and emmer (T. dicoccum; Maier \& Vogt 2001: 33). Each store contained almost pure deposits of a single cereal species; mixing of cereals within samples is attributed to the collapse of buildings and scattering of stores during the fire (Maier \& Vogt 2001: 38). Based on the quantity of cereal grains recovered from the sampled deposits, it has been estimated that 10-18ha of arable 


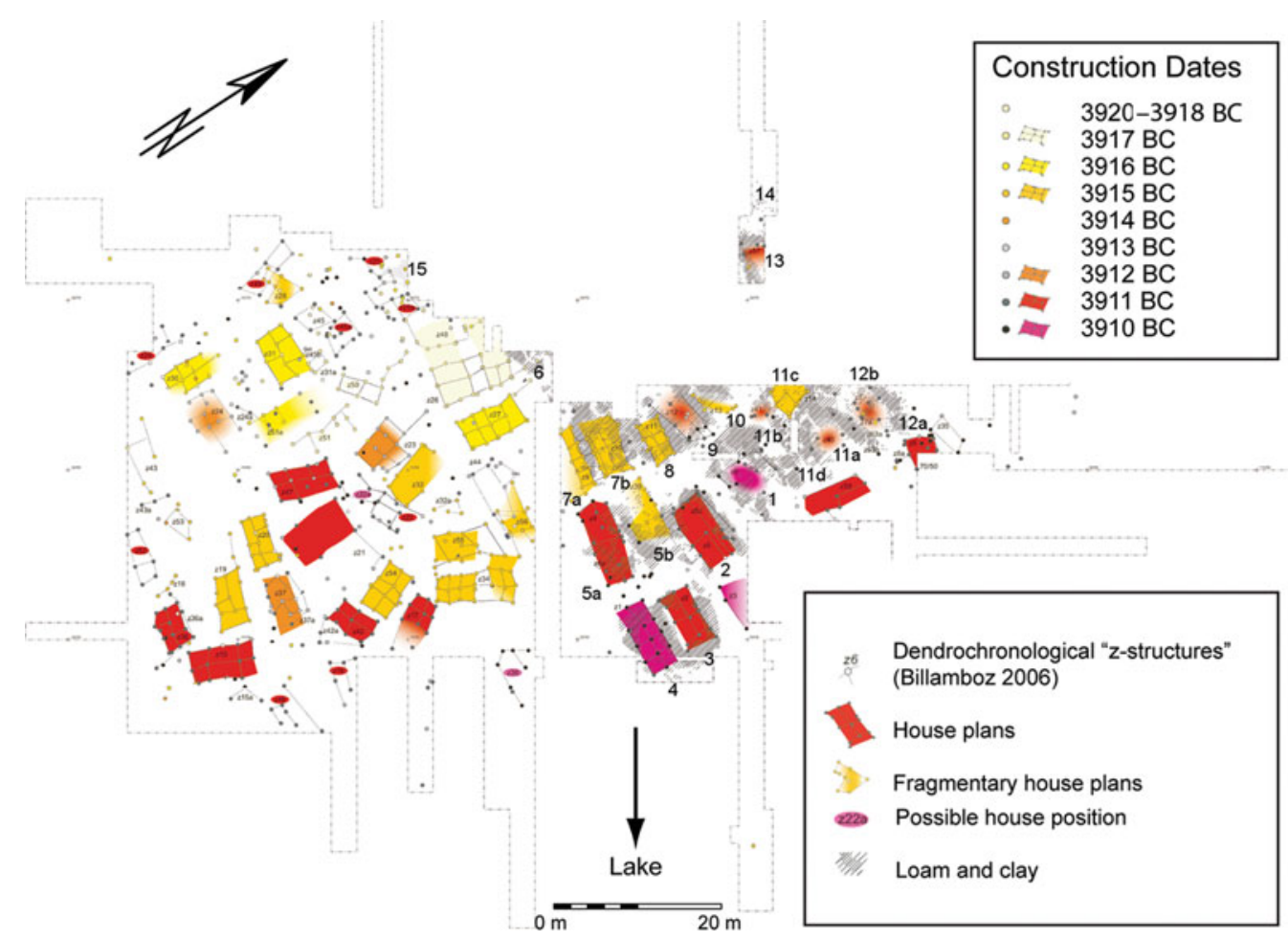

Figure 2. Plan of Hornstaad-Hörnle IA, showing the construction dates of houses built before the fire in 3910 cal BC (drawing by Arno Harwath, modified by Amy Styring); numbers 1-15 on the plan refer to the houses that have been identified in the burnt layer.

land would have been required to produce the cereal harvest for 40 houses. This could have been on the well-drained soils between 300-700m from the settlement (Maier 1999). The lack of perennial weed seeds, and particularly woodland species in the cereal stores, indicates that cultivation was continuous and not carried out on recently cleared plots (Maier 1999). Variation in the prevalence and diversity of weeds between stores implies differences in growing conditions between plots, but post-depositional mixing of cereal species within stores precludes comparison of growing conditions associated with different species or households (Maier \& Vogt 2001: 38).

Each house had its own 'toolkit' (Dieckmann et al. 2001), including wooden 'hand-ards', polished stone axes, flint points and fishing equipment, indicating that households were autonomous units, at least with regard to subsistence activities (cf. Ebersbach 2012). There seems, however, to be a pairing of houses in which certain plants, such as cornelian cherry (Cornus mas) — which at the time only grew on the southern slopes of the Alps—and objects associated with certain activities, such as bead production or fishing, were concentrated (Hoffstadt \& Maier 1999). The diversity in plant use and processing activities between individual and groups of households reflects findings from other lakeshore sites (Jacomet \& Brombacher 2005), illustrating varying degrees of inter-household cooperation as well as independence.

(C) Antiquity Publications Ltd, 2016 


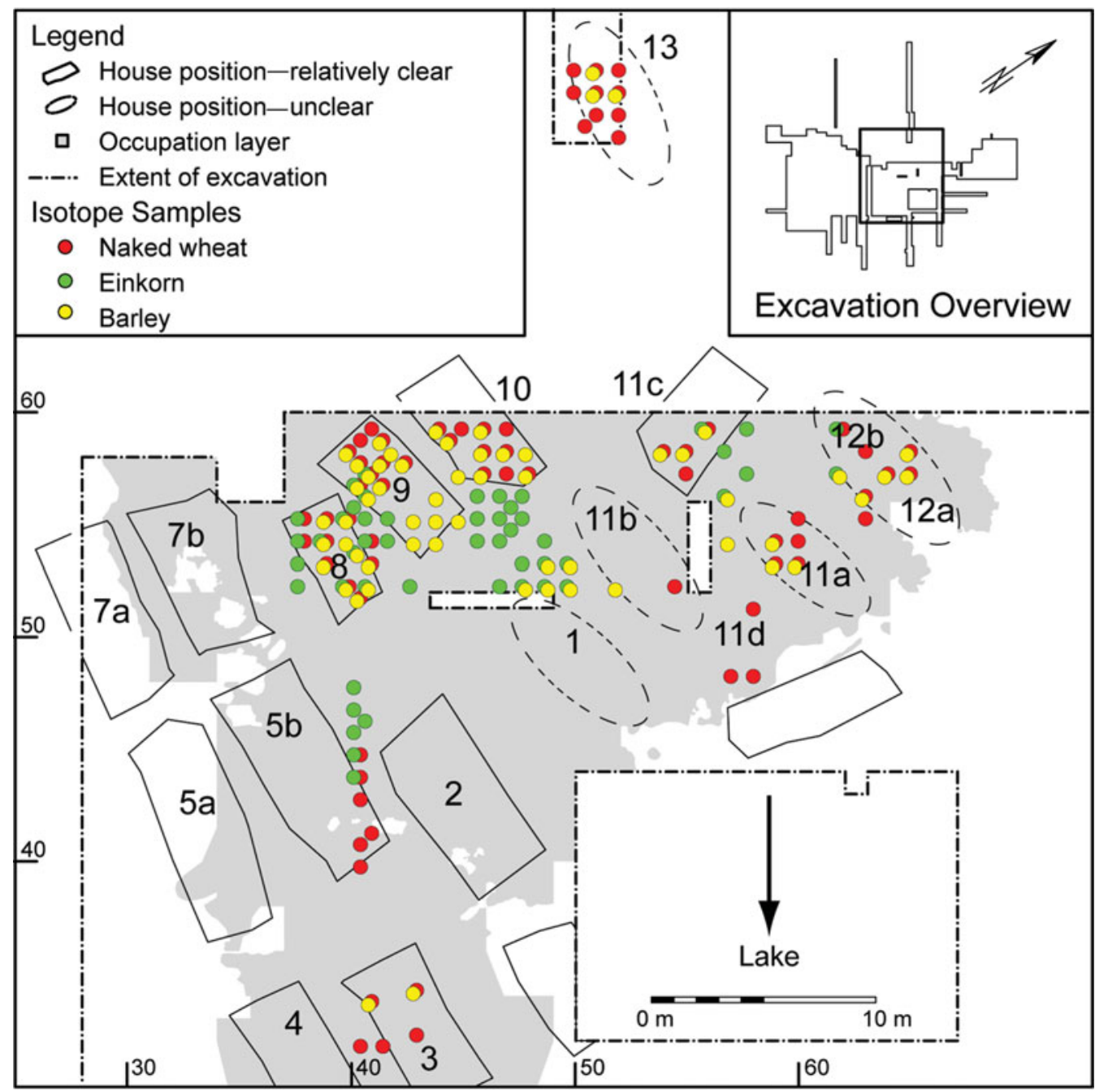

Figure 3. Plan of Hornstaad-Hörnle IA, showing location of the cereal grain samples selected for $\delta^{15} N$ analysis; the numbers indicate houses referred to in the text (drawing by Arno Harwath, modified by Amy Styring).

While these lines of evidence reveal much about the social geography of Hornstaad, isotopic analysis of the crop remains themselves has the potential to provide a direct and independent means of investigating cultivation practices and relationships between households. In particular, crop isotope analysis can address the question of whether households were autonomous at all levels of production, as implied by their individual toolkits, or whether they farmed communally, pooling the harvest before redistribution. This in turn has wider social implications, as communal farming implies some form of central management to coordinate the workforce. Communal farming could also be concomitant with more extensive farming practices-i.e. less intensive weeding/manuring on a larger scale to meet the village's needs, rather than smaller plots, intensively managed by individual 
households (Bogaard 2004: 54). Given the inherent disparity in the productivity of fixed plots of land (Halstead 1989), if farming was not communal, social mechanisms with varying degrees of formality must have been in place to redistribute surpluses in order to maintain what seems to have been a relatively egalitarian society (cf. Halstead 1989; Honegger 2005).

\section{Crop-growing conditions at Hornstaad-Hörnle IA}

Details of the analytical methods used may be found in the online supplementary material. There is a large variation in cereal grain $\delta^{15} \mathrm{~N}$ values $(2-11 \%$; Table S1),

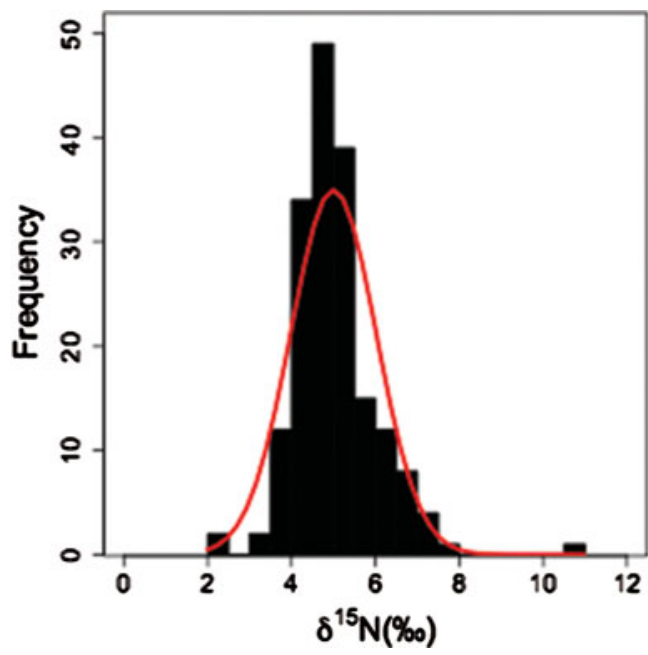

Figure 4. Histogram of cereal grain $\delta^{15} \mathrm{~N}$ values from Hornstaad-Hörnle IA; the red line plots the normal distribution. but the standard deviation is quite low (1\%o; Figure 4). The positive skew in the distribution of cereal $\delta^{15} \mathrm{~N}$ values is due to the very low proportion of cereal grains with $\delta^{15} \mathrm{~N}$ values $<4 \%$. As plant $\delta^{15} \mathrm{~N}$ values vary across locations, the best estimates of unmanaged plant $\delta^{15} \mathrm{~N}$ values derive from local herbivore bone collagen $\delta^{15} \mathrm{~N}$ values, which are used to gauge the $\delta^{15} \mathrm{~N}$ value of the plants on which they fed (for the method see the online supplementary material; cf. Bogaard et al. 2013). The cereal grain $\delta^{15} \mathrm{~N}$ values (mean $=5.0 \%$ ) at Hornstaad are consistently higher than the estimated unmanaged baseline $\delta^{15} \mathrm{~N}$ value (Figure 5), indicating that cereals were growing in soil significantly more enriched in ${ }^{15} \mathrm{~N}$ than that of the natural environment.

At Hornstaad, it is not probable that the high cereal grain $\delta^{15} \mathrm{~N}$ values were caused by recent forest clearance and burning, as the archaeobotanical weed assemblages contain few woodland species and are consistent with continuous cultivation (Maier 1999). It is also unfeasible that denitrification was the cause because weeds indicative of wet growing conditions were not found in the cereal stores (Maier \& Vogt 2001: 94), and detailed soil survey has identified well-drained soils, providing ample land for arable crops within $700 \mathrm{~m}$ of the village (Maier 1999). It is therefore most probable that the relatively high cereal grain $\delta^{15} \mathrm{~N}$ values are due to high organic soil nitrogen content-whether as a result of natural soil fertility or from the addition of organic nitrogen in manure. Cereal grain $\delta^{15} \mathrm{~N}$ values exceeding 4\%o have not been observed in modern, long-term experimental and traditional farming studies across Europe without the addition of manure (Fraser et al. 2011; Kanstrup et al. 2011). This strongly suggests that the cereals grown at Hornstaad were receiving manure but, given the variable range of $\delta^{15} \mathrm{~N}$ values, in different quantities. This suggestion agrees with the relatively high and varied $\delta^{15} \mathrm{~N}$ values of cereal grains recorded from previous analysis of the same layer (Bogaard et al. 2013). Moreover, manuring could account for the positive skew in the $\delta^{15} \mathrm{~N}$ distribution (Figure 4), if few cereal plots were receiving low (C) Antiquity Publications Ltd, 2016 
levels/no manure. Naked wheat and barley have slightly lower $\delta^{15} \mathrm{~N}$ values than einkorn ( $\mathrm{p}$ $<0.01$ ), but there is no significant difference between the $\delta^{15} \mathrm{~N}$ of naked wheat and barley at a village-wide level (Figure 5).

\section{Social geography of farming at Hornstaad-Hörnle IA}

As the cereal grains recovered at Hornstaad derive from a single harvest, their $\delta^{15} \mathrm{~N}$ values provide a unique opportunity to assess potential variation in crop-growing conditions and

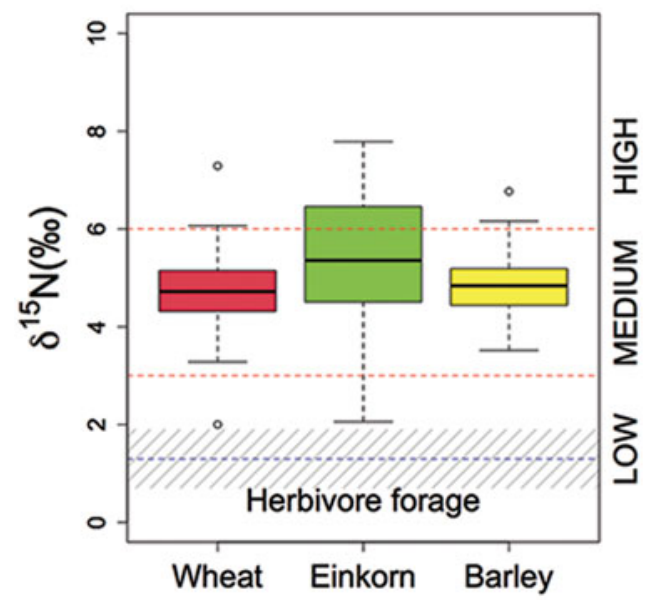

Figure 5. Boxplot of $\delta^{15} N$ values of carbonised naked wheat, einkorn and barley grain samples from HornstaadHörnle IA; the dashed blue line is the mean estimated herbivore plant diet (mean herbivore collagen $\delta^{15} \mathrm{~N}-4 \%$ ); grey shading is 1 standard deviation; manuring levels are defined from modern, long-term experimental farming plots (cf. Bogaard et al. 2013). agricultural decision-making among households, thereby illustrating the social dimension of crop-husbandry practices. Spatial analysis of the cereal grain $\delta^{15} \mathrm{~N}$ values using the Getis-Ord $\mathrm{Gi}^{*}$ statistic (Getis \& Ord 1992) shows clustering of similar values in certain households (Figure 6a-c; see online supplementary material). Such clustering eliminates the possibility that the harvest was pooled among all households prior to storage and thus provides independent support for the autonomy of these households at the level of production and subsistence (cf. Hoffstadt \& Maier 1999).

There is a clustering of high $\delta^{15} \mathrm{~N}$ values of naked wheat in houses 9 and $11 \mathrm{~d}$, contrasting with a cluster of low values in house 3 (Figure 6a). These clusters are confined to the houses in which they were found, despite the potential scattering of cereal grains when buildings collapsed during the fire. There is also clustering of einkorn $\delta^{15} \mathrm{~N}$ values, but locations of high/low einkorn $\delta^{15} \mathrm{~N}$ values do not overlap with those of naked wheat (Figure 6b). The einkorn from area $11 \mathrm{~b} / 1$ (between houses $11 \mathrm{~b}$ and 1 ) and area $8 / 9$ has relatively high $\delta^{15} \mathrm{~N}$ values, whereas the einkorn values from area $11 \mathrm{c} / 11 \mathrm{a}$ are relatively low. If the significantly different $\delta^{15} \mathrm{~N}$ values of wheat in these houses are due to variable levels of manuring, this indicates long-term differences between areas harvested by different houses. The discrete clusters of naked wheat $\delta^{15} \mathrm{~N}$ values in houses 8 and 9 indicates that they were cultivating wheat in different plots, under different cultivation conditions. This is interesting because the finds of cornelian cherries in these two neighbouring houses had suggested that they were paired (Hoffstadt \& Maier 1999).

In contrast to the wheats, there is little clustering of barley $\delta^{15} \mathrm{~N}$ values (Figure 6c). The range in barley $\delta^{15} \mathrm{~N}$ values across the site is 5.3\%o, larger than that determined for cereal grains receiving the same amount of manure and growing within a single modern field (Fraser et al. 2013). This implies that barley at Hornstaad was growing in a range 


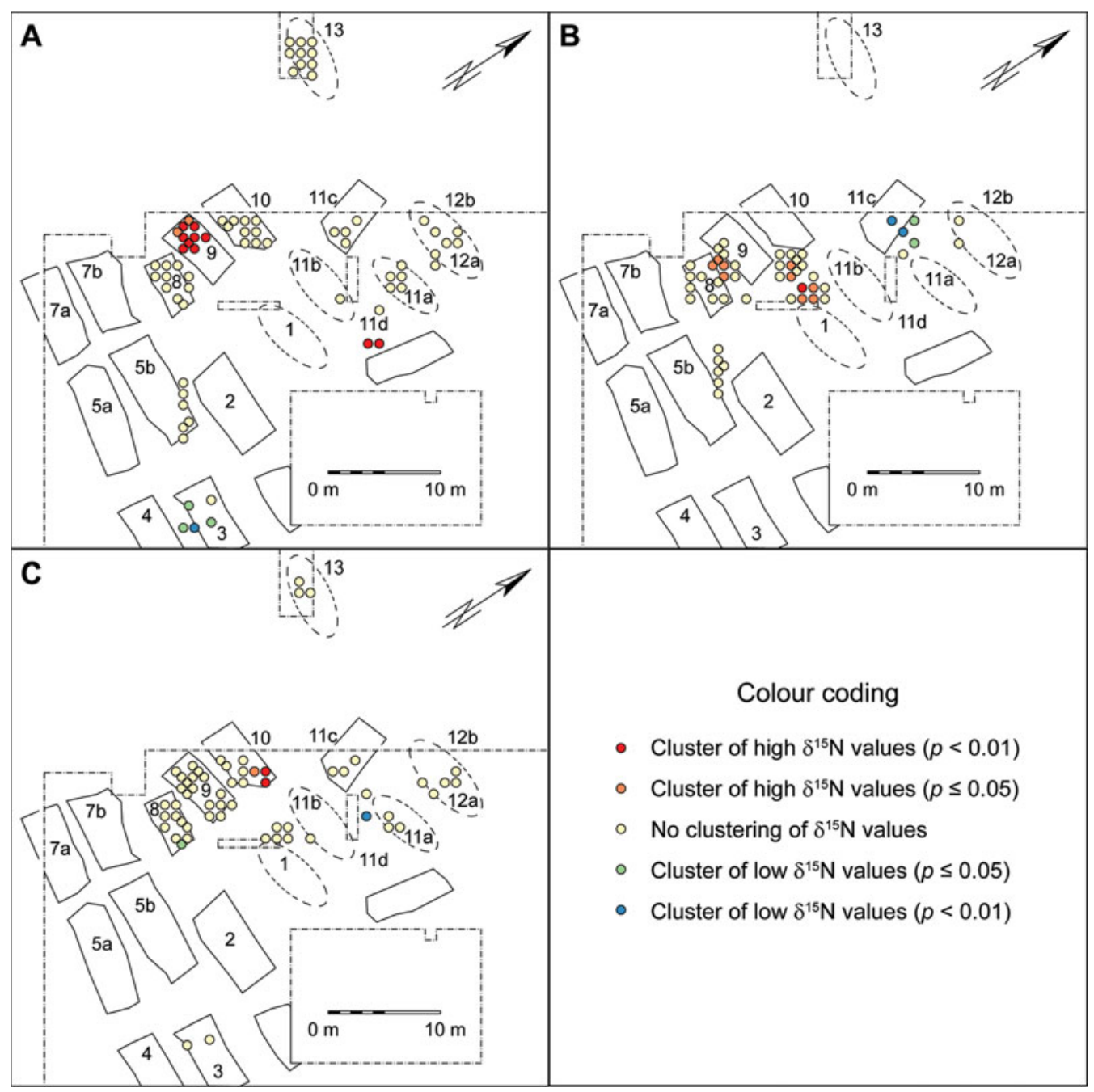

Figure 6. Spatial clustering of $\delta^{15} N$ values of: a) naked wheat; b) einkorn; and c) barley grain samples from HornstaadHörnle IA (drawing by Arno Harwath, modified by Amy Styring).

of conditions, potentially relating to manuring intensity, but that individual households were not manuring their barley variably enough to yield discrete clusters of different $\delta^{15} \mathrm{~N}$ values. This could indicate that households were opportunistically growing their barley on small patches of land, leading to high variability in barley $\delta^{15} \mathrm{~N}$ values within households. It is possible that barley was grown communally under different manuring conditions and then pooled prior to distribution, but this is not probable as this was not the case with the wheats. These contrasts between wheat and barley $\delta^{15} \mathrm{~N}$ value distributions correspond with different culinary uses: wheat was recovered in the remains of porridge and bread, while barley grains were probably roasted (Maier 1999; Maier \& Vogt 2001: 59). Crop $\delta^{15} \mathrm{~N}$ analysis on a household scale thus reveals differences in cultivation

(C) Antiquity Publications Ltd, 2016 
conditions between wheat and barley that are not evident when considered for the village as a whole.

\section{Sipplingen}

Sipplingen is situated on the northern shore of Lake Constance (Figure 1), about $14 \mathrm{~km}$ north-east of Hornstaad-Hörnle IA. Here, steep hills, up to $560 \mathrm{~m}$ in height, enclose a hilly area of approximately 200ha around the lake, itself 400m asl (Jacomet 1990). Baum (2014) modelled the area of arable land required to support 750 people_-a generous estimate of the settlement's population at its peak. Assuming intensive cultivation was practised (cf. Bogaard 2004: 113), this area was estimated to be $120 \mathrm{ha}$, which could be accommodated within the boundary of hills, whereas if crops were grown under a shifting cultivation regime, 2250ha of land would have been required (Baum 2014).

Sipplingen has a stratigraphic sequence of 15 cultural layers, dating from c. 4000 c. $2800 \mathrm{cal} \mathrm{BC}$, providing a detailed record of settlement in the area spanning the Hornstaad (3919-3902 cal BC), Pfyn (3870-3500 cal BC) and Horgen (c. 3300-2800 cal BC) cultures. Comprehensive dendroarchaeological, archaeobotanical and zooarchaeological investigations have revealed much about the changing nature of the settlement and its subsistence strategies over time. Isotopic analysis of the carbonised crop remains from the site provide a means of investigating how crop nitrogen isotope values changed throughout the settlement's occupation in response to changes in climate, environment and cultural influences.

The initial occupation of the lakeside bay in 3919-3904 cal BC (phase SiA) comprised two contemporary settlements. Houses were constructed with wood from primary forest, although some evidence for coppicing indicates that the area was probably populated and the forest exploited for wood before the site's occupation (cf. Billamboz 2012; Lechterbeck et al. 2014). Crop remains and wild plant resources from the forest were recovered in equal abundance from this layer, with einkorn being the most ubiquitous crop (Billamboz et al. 2013). The succeeding phase dates to the early Pfyn culture (SiB; 3857-3817 cal BC) and saw expansion from a hub of a few houses to its maximum extent in $3840 \mathrm{cal} \mathrm{BC}$, followed by a reduction in size around 3825 cal BC (Billamboz 2012). Houses were constructed from wood of varying ages, suggesting that clearance operations were small in scale rather than communal, and that different households exploited different areas of the forest (cf. Billamboz \& Köninger 2008).

Wild plant remains and animal bones (aurochs and red deer) decreased in abundance in the next phase of settlement, suggesting a diminished reliance on wild resources ( $\mathrm{SiC}$; $3795-$ $3786 \mathrm{cal} \mathrm{BC}$ ). The increasing economic importance of cultivated crops (mainly naked wheat and flax) and domestic cattle continued between 3727 and $3680 \mathrm{cal} \mathrm{BC} \mathrm{(SiD),} \mathrm{when} \mathrm{there}$ was also an increase in the size of the settlement and in levels of construction activity, using wood from increasingly degraded forest. Figure 7 shows the excellent state of preservation of a naked wheat ear from this layer. Within less than 80 years, there was a dramatic reversal in the economic importance of domestic crops and fauna, with the frequency of red deer bones surpassing those of cattle, and the concentration of cereals in the botanical assemblage dropping considerably (SiE; Steppan \& Stephan 2012; Billamboz et al. 2013). 

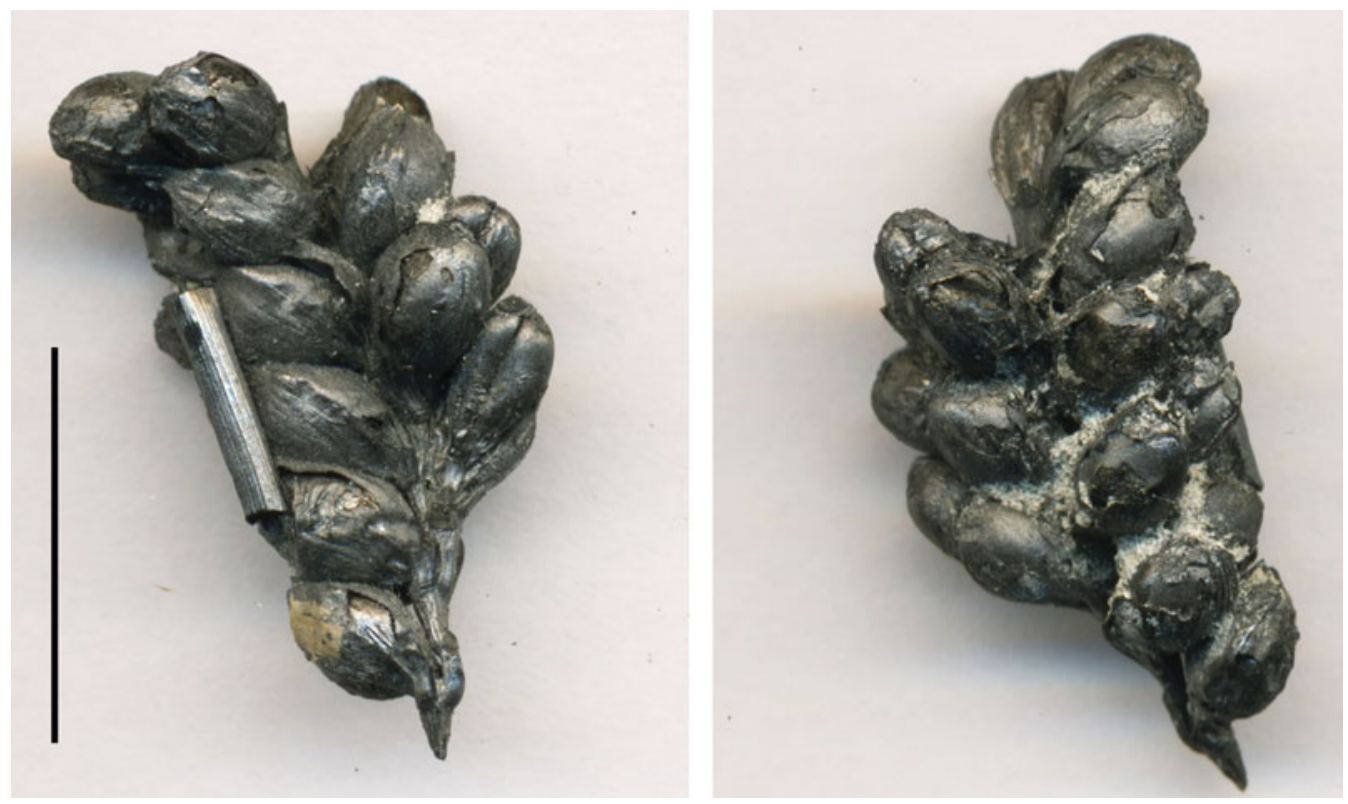

Figure 7. Photograph of both sides of a naked wheat ear (T. durum/turgidum) recovered from layer SiD at Sipplingen (photograph by Amy Styring); the line represents $10 \mathrm{~mm}$.

This coincided with a reduction in settlement size, followed by a hiatus in settlement occupation for 300 years, from 3600-3300 cal BC (Billamboz 2012). Similarly dramatic economic changes occurred at Swiss lakeshore sites at the time, and have been attributed to climatic deterioration and a rise in lake levels (Schibler et al. 1997). At Sipplingen, severe degradation of the forest due to felling may have led to a shortage of wild resources, which also contributed to the site's abandonment. This cycle of establishment, expansion and then reduction (and in some cases abandonment) is common across lakeshore sites around Lake Constance (Billamboz \& Köninger 2008), but, in this instance, it seems to have been hastened by climatic decline.

During the settlement hiatus, reforestation occurred (Lechterbeck et al. 2014), and reoccupation of the site at the beginning of the Horgen culture in $3316 \mathrm{cal} \mathrm{BC}(\mathrm{SiG})$ used wood from established trees for house construction (Billamboz 2012). For the next 300 years, from 3300-3000 cal BC, there was another cycle of initial clearance followed by increasing exploitation and degradation of the forest. Emmer (T. dicoccum) was now the most economically important cereal while cultivation of opium poppies (P. somniferum) increased. Pig bones became more numerous, which could reflect more intensive forest management, and cattle numbers increased, probably due to their use as draft animals from c. 3150 cal BC (SiJ/K; cf. Hüster-Plogmann \& Schibler 1997). It is also during this phase that a new harvesting method was introduced: sickles were replaced by harvesting knives, which are believed to have been more efficient and allowed a larger cereal harvest (Billamboz et al. 2013).

(C) Antiquity Publications Ltd, 2016 
Pfyn Culture

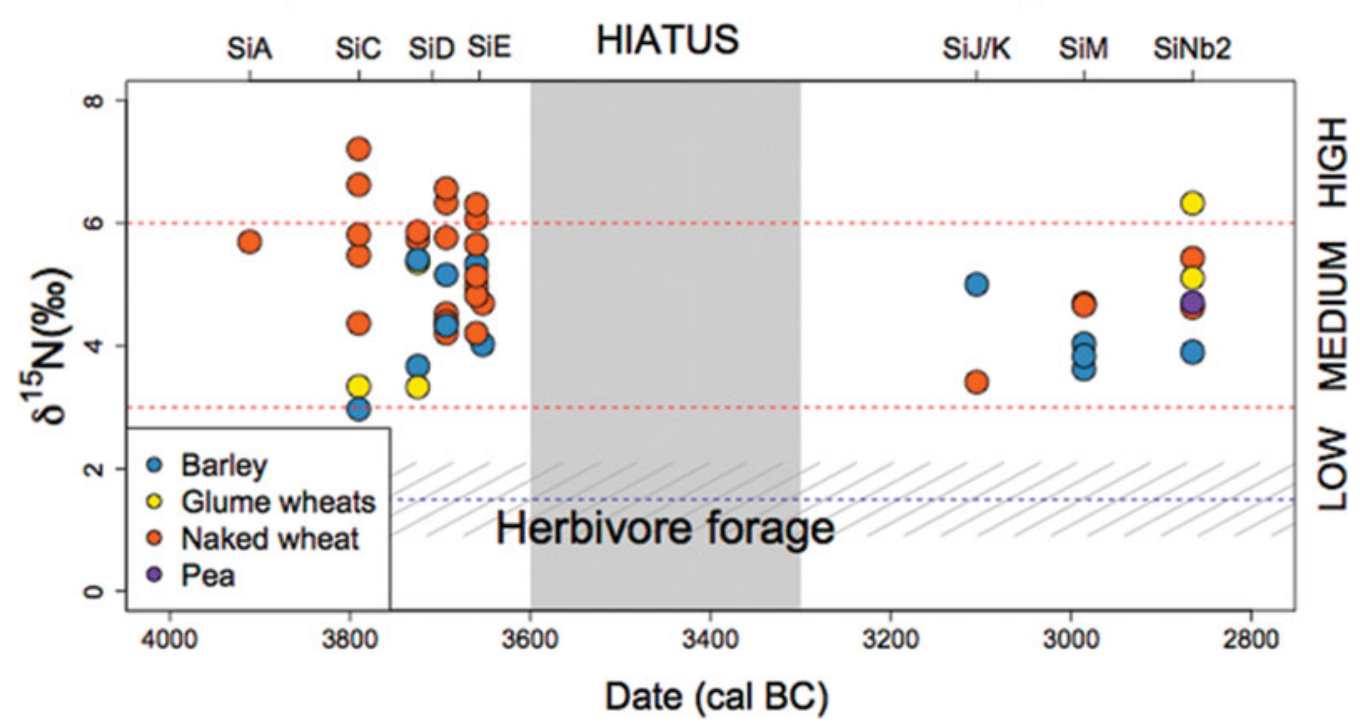

Figure 8. Crop $\delta^{15} N$ values during the occupation of Sipplingen, from c. 4000-2800 cal BC; the dashed blue line is the mean estimated herbivore plant diet (mean herbivore collagen $\delta^{15} \mathrm{~N}-4 \%$ ); the grey shading is 1 standard deviation; manuring levels are defined from modern, long-term experimental farming plots (cf. Bogaard et al. 2013).

Both the settlement layout and use of the forest changed dramatically in the later Horgen period ( $\mathrm{SiN}$; 2925-2855 cal BC). Large houses were arranged along a single entry road, and a palisade surrounded the houses on the landward side of the settlement, echoing the layout of other settlements at this time (Billamboz 2012). Houses were constructed using trees of a similar age, implying a more rigid and coordinated management of the forest. Weed seeds and pollen analysis suggest that the landscape was now more open, with little dense woodland and extensive pasture and fallow fields (Jacomet 1990; Lechterbeck et al. 2014). During 2876-2855 cal BC (SiNb2), all plants decreased in frequency, and, while pigs also decreased in number, the remains of red deer became more common, suggesting an increased reliance on hunting. This period marks the end of the Horgen culture.

\section{Change in crop-growing conditions over 1000 years at Sipplingen}

Details of the analytical methods used can be found in the online supplementary material. The $\delta^{15} \mathrm{~N}$ values of cereal grains from Sipplingen range from 3-7.2\%o (Table S2), with a mean of $5 \%$. As observed at Hornstaad-Hörnle IA, the cereal grain $\delta^{15} \mathrm{~N}$ values are consistently higher than the $\delta^{15} \mathrm{~N}$ value estimated for unmanaged plants on the site (estimated from the mean herbivore bone collagen $\delta^{15} \mathrm{~N}$ value of 5.5\%o, as determined by Steppan and Stephan 2012; Figure 8), indicating that cereals at Sipplingen were also growing in soil significantly more enriched in ${ }^{15} \mathrm{~N}$ than that of the natural environment. These $\delta^{15} \mathrm{~N}$ values are consistent with a medium-high level of manuring. 
Throughout the settlement's occupation, naked wheat $\delta^{15} \mathrm{~N}$ values are significantly higher than barley $\delta^{15} \mathrm{~N}(\mathrm{t}(29)=2.534, \mathrm{p}=0.017$; Figure 8). This indicates a deliberate and sustained difference in the cultivation of these two cereals, suggesting that they occupied different ecological and, potentially, social niches throughout the Late Neolithic. Such a finding also agrees with the conclusions of Riehl (2004), who, based on archaeobotanical analysis of crop remains from phase $\mathrm{SiD}$, suggests that economic differences could explain why naked and glume wheats were stored in their ears, whereas barley was threshed before storage. This difference is less pronounced in the post-hiatus occupation, however, with barley $\delta^{15} \mathrm{~N}$ values staying relatively constant, while naked wheat $\delta^{15} \mathrm{~N}$ values significantly decrease $(\mathrm{t}(25)=-2.185, \mathrm{p}=0.038)$.

It is striking that naked wheat and barley $\delta^{15} \mathrm{~N}$ values do not change significantly throughout the Pfyn culture. This is despite the dendroarchaeological, palynological and archaeobotanical evidence for increased clearance of the forest (Billamboz 2012; Lechterbeck et al. 2014), presumably leading to an expansion of arable cultivation and a greater pressure on manure supply. Most noteworthy is that naked wheat and barley $\delta^{15} \mathrm{~N}$ values do not change in the years immediately leading up to the settlement hiatus, when the decreased abundance of crops and increase in wild animal bones on the site has been interpreted as evidence of successive crop failures leading to an increased reliance on wild resources (Schibler et al. 1997). The recalcitrance of soil organic nitrogen could go some way to explaining the lack of change in crop $\delta^{15} \mathrm{~N}$ values, as the $\delta^{15} \mathrm{~N}$ value of bread wheat grown on previously manured plots at the long-term experimental site of Rothamsted, UK, took 70 years to decrease below 3\% with no manure, having previously had a $\delta^{15} \mathrm{~N}$ value of 6\%o (Fraser et al. 2011). Manuring levels must, however, have been maintained throughout most of the Pfyn culture, and given that crop $\delta^{15} \mathrm{~N}$ values did not fall below 3\%, it appears that the majority of manure nitrogen had not been exhausted. This supports the hypothesis that the abandonment of the settlement was as a result of climatic deterioration, rather than degradation of the soil (cf. Schibler et al. 1997).

Following the 300-year gap in settlement occupation, emmer replaced naked wheat as the most ubiquitous cereal species. This coincides with a decrease in naked wheat $\delta^{15} \mathrm{~N}$ values, suggesting that as it was no longer the most economically important cereal crop, it was not being manured as intensively, although this interpretation remains tentative due to the low number of samples. This inference is supported by the fact that the $\delta^{15} \mathrm{~N}$ values of glume wheat samples (emmer and einkorn), albeit scarce, are higher than those of naked wheat for the first time. Again, it is pertinent that the crop $\delta^{15} \mathrm{~N}$ values are generally consistent with medium-high levels of manuring, indicating that manure was still a valued and widely exploited resource. It is believed that agriculture became more extensive in the Horgen period, as larger areas of forest were cleared and cattle were used as draft animals. Nevertheless, the crop $\delta^{15} \mathrm{~N}$ values indicate that manuring levels were maintained, possibly due to greater availability with the growing importance of cattle. The crop $\delta^{15} \mathrm{~N}$ results demonstrate that, although the adoption of draft animals suggests a shift towards more extensive farming regimes by reducing the human labour required to prepare a given area, there was no radical shift to a fundamentally different farming system, with lower inputs per unit area (cf. Isaakidou 2011). 
The very high $\delta^{15} \mathrm{~N}$ value of a sample of peas (Pisum sativum) from the latest phase of the site further alludes to an abundance of organic-rich waste around the settlement itself, which is also implied by an abundance of weed seeds characteristic of eutrophication (Billamboz et al. 2013). The $\delta^{15} \mathrm{~N}$ value of $4.7 \%$ is very high for pulses, as in the absence of manure they generally have $\delta^{15} \mathrm{~N}$ values close to that of atmospheric N (0\%o; Yoneyama et al. 1986), and experimental plots of peas and broad beans receiving up to 30 tonnes/ha manure also show no increase in their $\delta^{15} \mathrm{~N}$ values (Fraser et al. 2011). In fact, the only pulses with such high $\delta^{15} \mathrm{~N}$ values in modern situations were grown on small garden plots manured so intensively that they formed artificial 'dung-soil' (Fraser et al. 2011). Given that the ubiquity of pulses is very low on the site (Billamboz et al. 2013), this could indicate that they were grown in small garden plots close to people's houses, where they could receive high levels of manure or household waste.

In the final phase of the settlement for which we have crop remains (SiNb2; 2876-2855 cal BC), it is curious that despite dramatic changes in both the settlement layout and use of the forest (Billamboz 2012), there is no corresponding change in the crop $\delta^{15} \mathrm{~N}$ values that can be detected in the available samples. This implies that manuring levels were maintained, as management of the forest and layout of the settlement became more regulated.

\section{Conclusions}

Nitrogen isotope analysis of crop remains has shown how arable land management varied both within a community and throughout time, enriching our knowledge of farming practices beyond that of general depictions. For the first time, cultivation choices, probably regarding manure use, have been shown to take place at a household level at Hornstaad-Hörnle IA, highlighting the differential availability of this important resource and demonstrating the potential of crop nitrogen isotope studies for further understanding social geography in the Neolithic. Moreover, as organic-N turnover is relatively slow, differences in crop $\delta^{15} \mathrm{~N}$ reflect long-lived management decisions and social dynamics, probably surpassing the lifetime of the houses themselves (Billamboz 2006). The consistent difference in $\delta^{15} \mathrm{~N}$ of naked wheat and barley prevailed at Sipplingen for over 1000 years, indicating that these crops occupied different ecological and social niches in the Late Neolithic. A decrease in the abundance and $\delta^{15} \mathrm{~N}$ values of naked wheat at Sipplingen during the Horgen cultural phase reflects its changing status, as it was replaced by emmer as the dominant cereal. The overall continuity in crop $\delta^{15} \mathrm{~N}$ values over time at Sipplingen reflects sustained investment in the land, maintaining levels of manuring despite pressure from wider economic drivers, such as the expansion of agricultural land and changes in land management strategies, and notwithstanding a hiatus in settlement occupation. New technological developments, such as the adoption of cattle as draft animals, were incorporated into a well-established intensive agricultural system that persisted for over 1000 years.

\section{Acknowledgements}

The work reported here was funded by the European Research Council (AGRICURB project, grant 312785, PI Bogaard). We would also like to thank Arno Harwath for help with the preparation of the Hornstaad-Hörnle 
IA plans; Bodo Dieckmann, Jutta Hoffstadt, Oliver Nelle and Richard Vogt for useful discussion of the results. We would also like to thank Irenäus Matuschik for helpful comments on the manuscript.

\section{Supplementary material}

To view supplementary material for this article, please visit http://dx.doi.org/ 10.15184/aqy.2015.192

\section{References}

Aguilera, M., J.L. Araus, J. Voltas, M.O. Rodríguez-ArizA, F. Molina, N. RovirA, R. BuxÓ \& J.P. FERRIO. 2008. Stable carbon and nitrogen isotopes and quality traits of fossil cereal grains provide clues on sustainability at the beginnings of Mediterranean agriculture. Rapid Communications in Mass Spectrometry 22: 1653-63. http://dx.doi.org/10.1002/rcm.3501

BAUM, T.G. 2014. Models of wetland settlement and associated land use in south-west Germany during the fourth millennium B.C. Vegetation History and Archaeobotany 23: 67-80.

http://dx.doi.org/10.1007/s00334-014-0453-3

Billamboz, A. 2006. Dendroarchäologische Untersuchungen in den neolithischen Ufersiedlungen von Hornstaad-Hörnle, in B. Dieckmann, A. Harwath, J. Hoffstadt \& A. Billamboz (ed.) Siedlungsarchäologie im Alpenvorland IX (Forschungen und Berichte zur Vor- und Frühgeschichte in Baden-Württemberg 98): 297-414. Stuttgart: Konrad Theiss.

- 2012. Les villages néolithiques de la baie de Sipplingen sur le lac de Constance: rhythmes de l'occupation dans le contexte de l'économie forestière, in M. Honegger \& C. Mordant (ed.) L'homme au bord de l'eau: archéologie des zones littorales du Néolithique à la protohistoire: 299-314. Lausanne: Cahiers d'archéologie romande.

Billamboz, A. \& J. KöNinger. 2008.

Dendroarchäologische Untersuchungen zur Besiedlungs- und Landschaftsentwicklung im Neolithikum des westlichen Bodenseegebietes, in W. Dörfler \& J. Müller (ed.) Umwelt, Wirtschaft, Siedlungen im dritten vorchristlichen Jahrtausend Mitteleuropas und Südskandinaviens: 317-34. Kiel: Wachholz Verlag Neumünster.

Billamboz, A., T. Baum, M. Kaiser, U. Maier, I. MatuschiK, A. MÜller, E. STEPHAN, K. Steppan, H. Schlichtherle \& R. Vogt. 2013. Abschlussbericht zu 'Das Sipplinger Dreieck als Modell jung- und endneolithischer Siedlungs- und Wirtschaftsdynamik am Bodensee' (PL 95/49-1/SCHL 398/2-2). Unpublished report.

BOGAARD, A. 2004. Neolithic farming in central Europe. London: Routledge.

(C) Antiquity Publications Ltd, 2016
Bogaard, A., R. Fraser, T.H.E. Heaton, M. Wallace, P. Vaiglova, M. Charles, G. Jones, R.P. EVERSHED, A.K. STYRING, N.H. ANDERSEN, R.-M. Arbogast, L. Bartosiewicz, A. Gardeisen, M. Kanstrup, U. Maier, E. Marinova, L. Ninov, M. SCHÄFER \& E. STEPHAN. 2013. Crop manuring and intensive land management by Europe's first farmers. Proceedings of the National Academy of Sciences 110: 12589-94. http://dx.doi.org/10.1073/pnas.1305918110

BrombaCHER, C. \& S. JACOMET. 1997. Ackerbau, Sammelwirtschaft und Umwelt: Ergebnisse archäobotanischer Untersuchungen, in J. Schibler, H. Hüster-Plogmann, S. Jacomet, C. Brombacher, E. Gross-Klee \& A. Rast-Eicher (ed.) Ökonomie und Ökologie neolithischer und bronzezeitlicher Ufersiedlungen am Zürichsee: 220-91. Zürich: Direktion der öffentlichen Bauten des Kantons Zürich.

Dieckmann, B., U. Maier \& R. Vogt. 2001. Hornstaad: zur inneren Dynamik einer jungneolithischen Dorfanlage am westlichen Bodensee. Neue Ergebnisse der Archäologie, Botanik und Bodenkunde, in A. Lippert, M. Schulz, S. Shennan \& M. Teschler-Nicola (ed.) Mensch und Umwelt während des Neolithikums und der Frühbronzezeit in Mitteleuropa: 29-51. Rahden: Marie Leidorf GmbH.

EBERSBACH, R. 2012. Houses, households, and settlements: architecture and living spaces, in F. Menotti \& A. O'Sullivan (ed.) The Oxford handbook of wetland archaeology: 283-302. Oxford: Oxford University Press.

Ehrmann, O., H. Biester, A. Bogenrieder \& M. RÖSCH. 2014. Fifteen years of the Forchtenberg experiment-results and implications for the understanding of Neolithic land use. Vegetation History and Archaeobotany 23: 5-18. http://dx.doi.org/10.1007/s00334-014-0452-4

Finlay, J.C. \& C. Kendall. 2008. Stable isotope tracing of temporal and spatial variability in organic matter sources to freshwater ecosystems, in R. Michener \& K. Lajtha (ed.) Stable isotopes in ecology and environmental science: 283-333. Oxford: Blackwell. 


\section{Cultivation of choice}

Fraser, R.A., A. BogaArd, T.H.E. Heaton, M. Charles, G. Jones, B.T. Christensen, P. Halstead, I. Merbach, P.R. Poulton, D. SPARKES \& A.K. STYRING. 2011. Manuring and stable nitrogen isotope ratios in cereals and pulses: towards a new archaeobotanical approach to the inference of land use and dietary practices. Journal of Archaeological Science 38: 2790-2804. http://dx.doi.org/10.1016/j.jas.2011.06.024

Fraser, R.A., A. BogaArd, M. Charles, A.K. Styring, M. Wallace, G. Jones, P. Ditchfield \& T.H.E. Heaton. 2013. Assessing natural variation and the effects of charring, burial and pre-treatment on the stable carbon and nitrogen isotope values of archaeobotanical cereals and pulses. Journal of Archaeological Science 40: 4754-66. http://dx.doi.org/10.1016/j.jas.2013.01.032

GeTis, A. \& J. ORD. 1992. The analysis of spatial association by use of distance statistics. Geographical Analysis 24: 189-206. http://dx.doi.org/10.1111/ j.1538-4632.1992.tb00261.x

HAlsteAD, P. 1987. Traditional and ancient rural economy in Mediterranean Europe: plus ça change? Journal of Hellenic Studies 107: 77-87. http://dx.doi.org/10.2307/630071

- 1989. The economy has a normal surplus: economic stability and social change among early farming communities of Thessaly, Greece, in Bad year economics: cultural responses to risk and uncertainty: 68-80. Cambridge: Cambridge University Press.

Hoffstadt, J. \& U. MAiER. 1999. Handelsbeziehungen während des Jungneolithikums im westlichen Bodenseeraum am Beispiel der Fundplätze Mooshof und Hornstaad Hörnle IA. Archäologisches Korrespondenzblatt 29: 21-34.

HöGBERG, P. 1997. Tansley review $95 .{ }^{15} \mathrm{~N}$ natural abundance in soil-plant systems. New Phytologist 137: 179-203. http://dx.doi.org/10.1046/j.14698137.1997.00808.x

Honegger, M. 2005. Les villages littoraux du Néolithique: égalité et autarcie ou complémentarité et mise en réseau?, in WES'04-Wetland Economies and Societies: Proceedings of the International Conference, Zurich, 10-13 March 2004: 185-94. Zürich: Chronos.

Hüster-Plogmann, H. \& J. Schibler. 1997. Archäozoologie, in J. Schibler, H. Hüster-Plogmann, S. Jacomet, C. Brombacher, E. Gross-Klee \& A. Rast-Eicher (ed.) Ökonomie und Ökologie neolithischer und bronzezeitlicher Ufersiedlungen am Zürichsee: 40-121. Zürich: Direktion der öffentlichen Bauten des Kantons Zürich.
ISAAKIDOU, V. 2011. Farming regimes in Neolithic Europe: gardening with cows and other models, in A. Hadjikoumis, E. Robinson \& S. Viner-Daniels (ed.) The dynamics of neolithisation in Europe: studies in honour of Andrew Sherratt: 90-112. Oxford: Oxbow.

JACOMET, S. 1990. Veränderungen von Wirtschaft und Umwelt während des Spätneolithikums im westlichen Bodenseegebiet. Ergebnisse samenanalytischer Untersuchungen an einem Profilblock aus der Horgener Stratigraphie von Sipplingen-Osthafen (Tauchsondierung Ruoff 1980), in Siedlungsarchäologie im Alpenvorland II: 295-324. Stuttgart: Konrad Theiss.

JACOMET, S. \& C. BROMBACHER. 2005. Reconstructing intra-site patterns in Neolithic lakeshore settlements: the state of archaeobotanical research and future prospects, in WES'O4-Wetland Economies and Societies: Proceedings of the International Conference, Zurich, 10-13 March 2004: 69-94. Zürich: Chronos.

Kanstrup, M., I.K. Thomsen, A.J. Andersen, A. BogaArd \& B.T. Christensen. 2011. Abundance of ${ }^{13} \mathrm{C}$ and ${ }^{15} \mathrm{~N}$ in emmer, spelt and naked barley grown on differently manured soils: towards a method for identifying past manuring practice. Rapid Communications in Mass Spectrometry 25: 2879-87. http://dx.doi.org/10.1002/rcm.5176

LeChterbeck, J., K. Edinborough, T. Kerig, R. Fyfe, N. Roberts \& S. Shennan. 2014. Is Neolithic land use correlated with demography? An evaluation of pollen-derived land cover and radiocarbon-inferred demographic change from Central Europe. The Holocene 24: 1297-1307. http://dx.doi.org/10.1177/0959683614540952

MaIER, U. 1999. Agricultural activities and land use in a Neolithic village around 3900 B.C.: Hornstaad Hörnle IA, Lake Constance, Germany. Vegetation History and Archaeobotany 8: 87-94.

MAIER, U. \& R. VOGT. 2001. Siedlungsarchäologie im Alpenvorland VI (Forschungen und Berichte zur Vor- Und Frühgeschichte in Baden-Württemberg 74). Stuttgart: Konrad Theiss. http://dx.doi.org/10.1007/BF02042846

RIEHL, S. 2004. Jungneolithische Pflanzenproduktion und Nutzung des Naturraums am Überlinger See/Bodensee: Archäobotanische Untersuchungen an Kulturschichtsedimenten aus der Seeufersiedlung Sipplingen, in Siedlungen der Pfyner Kultur im Osten der Pfahlbaubucht von Sipplingen, Bodenseekreis Bd. 2, Naturwissenschaftiche Untersuchungen: 9-76. Freiburg i. Br.: Hemmenhofener Skripte 4.

Schibler, J., S. Jacomet, H. Hưster-Plogmann \& C. BROMBACHER. 1997. Economic crash in the $37^{\text {th }}$ and $36^{\text {th }}$ centuries cal. BC in Neolithic lake shore sites in Switzerland. Anthropozoologica 25: 553-70. 


\section{Amy Styring et al.}

Steppan, K. \& E. STEPHAN. 2012. Archäolzoologische und isotopenchemische aspeckte der jungsteinzeitlichen wirtschafts- und umweltdynamik im Sipplinger Dreieck, Bodenseekreis, in F. Schlütter, S. Greiff \& M. Prange (ed.) Archäometrie und Denkmalpflege 2012: 89-91.
Yoneyama, T., K. Fujita, T. Yoshida, T. Matsumoto, I. KAMBAYASHI \& J. YAZAKI. 1986. Variation in natural abundance of ${ }^{15} \mathrm{~N}$ among plant parts and in ${ }^{15} \mathrm{~N} /{ }^{14} \mathrm{~N}$ fractionation during $\mathrm{N}_{2}$ fixation in the legume-rhizobia symbiotic system. Plant and Cell Physiology 27: 791-99.

Received: 12 December 2014; Accepted: 19 March 2015; Revised: 7 April 2015

C) Antiquity Publications Ltd, 2016 